\title{
The Need for Coordination Among Firms, with Special Reference to Network Industries*
}

\author{
Dennis W. Carlton† and J. Mark Klamer $\dagger \dagger$
}

Coordination among firms presents a policy dilemma. Efficiency may require coordinated action, but coordinated action can stifle competition and make collusion more likely. This policy dilemma arises frequently, as, for example, in cases involving information exchanges among competing firms. ${ }^{1}$ Knowing a competitor's price makes it easier not only to set prices in line with the market, but also to fix prices noncompetitively.

The setting of physical product standards ${ }^{2}$ also illustrates the trade-off between efficiency and competition. Standards can have obvious efficiency effects, yet they can also be a tool by which established firms exclude entrants. The case of Radiant Burners, Inc. v. Peoples Gas Light \& Coke Co. ${ }^{3}$ demonstrates the way in which standard setting can be an anticompetitive practice. ${ }^{4}$ The

* We wish to thank Douglas Baird, Frank Easterbrook, Daniel Fischel, William Landes, Warren Lavey, John Mooney, and Richard Posner for helpful comments. This work has been stimulated in part by associations with AT\&T and Bell Laboratories, although the article reflects the views of the authors alone.

$\dagger$ Professor of Economics, University of Chicago Law School.

t† Harvard Law School (J.D. Class of 1985).

${ }^{1}$ See, e.g., United States v. United States Gypsum Co., 438 U.S. 422 (1978); United States v. Container Corp. of Am., 393 U.S. 333 (1969); Maple Flooring Mfrs. Ass'n v. United States, 268 U.S. 563 (1925); American Column \& Lumber Co. v. United States, 257 U.S. 377 (1921). See also Posner, Information and Antitrust: Reflections on the Gypsum and Engineers Decisions, 67 GEo. L.J. 1187 (1979).

For a game theoretic investigation of when independent actions of firms cannot be relied upon to lead to an efficient equilibrium, see L. TelSER, Economic THEORY AND THE Core (1978). See also Bittlingmayer, Decreasing Average Cost and Competition: A New Look at the Addyston Pipe Case, 25 J.L. Econ. 201 (1982); L. Telser, Genesis of the Sherman Act (Dec. 1982) (unpublished working paper No. 24, Center for the Study of the Economy and the State, University of Chicago).

2 Physical standards provide physical specifications for certain goods, such as screw sizes, railroad track size, and video and audio tape sizes. See infra notes 9-14 and accompanying text.

364 U.S. 656 (1961).

- For other examples in which standard setting has been alleged to exclude competitors, see J. Mooney, R. Schroeder, D. Graybill \& W. Lovejoy, Standards and Certification, Proposed Rule and Stapf Report 234-39 (1978). 
Supreme Court found a cause of action in the plaintiff's allegation that the American Gas Association conspired with its member utilities to deny its seal of approval to the plaintiff's gas burner, which the plaintiff alleged was safer than burners approved by the Association. The complaint further alleged that the standards were chosen to insulate existing firms from competition. ${ }^{5}$

The trade-off between efficiency and competition also arises in network industries. ${ }^{6}$ For example, a key goal of the Justice Department's recent settlement of its antitrust suit against AT\&T was to create competition among several phone companies without destroying the efficiency of a coordinated long-distance network. ${ }^{7}$ Similarly, efficiency often results from horizontal mergers of railroads, although such mergers might lessen competition in some areas. ${ }^{8}$

This paper discusses how coordinated action among firms in the same industry may be necessary to achieve efficiency. There is no simple way to determine when an efficiency gain from coordinated action will outweigh the loss of competition, but it is important nonetheless to understand when a large efficiency gain is most likely to occur. For that reason, we will discuss the problems associated with standard setting and network industries, areas in which concerted action can produce large efficiency gains. The paper will then apply the analysis to several examples: railroads during the nineteenth century, the telephone industry, and the newly emerging electronic funds transfer industry.

\section{A Theory of Efricient Interfirm Coordination}

\section{A. Standards: A Simple Case of Beneficial Coordination}

One of the simplest examples of beneficial coordination among suppliers is agreement on physical standards for a product. Standard part sizes, for example, are a great convenience for consumers. Without standard sizes, a consumer who needed to replace a part would be forced to search extensively among suppliers or to locate the original manufacturer. Standards lower consumer search

s 364 U.S. at 657.

- For a definition of network industries, see infra text proceeding note 15.

7 See Department of Justice Antitrust Division, Competitive Impact Statement in Connection with Proposed Modification of Final Judgment, 47 Fed. Reg. 7170 (1982).

- For example, the ICC, although recognizing that the merger could lead to a lessening of competition in some areas, has recently approved a large horizontal merger of the Union Pacific and the Missouri and Western Pacific Railroads. N.Y. Times, Sept. 14, 1982, at A1, col. 1, D5, col. 2. 
and information costs and thus enhance competition. Physical standards can also have a substantial impact on dynamic efficiency. A recent FTC investigation of standards pointed out instances where innovation was likely retarded either because outdated standards were in force or because existing standards were too restrictive. ${ }^{\ominus}$

The establishment of standard and uniform operating procedures, such as uniform accounting systems, ${ }^{10}$ can also be very important in achieving efficient operations. Common operating procedures are especially critical for the efficient operation of a network industry because of the great degree of coordination required for efficient operations.

In assessing the benefits of coordination, it is important to understand how standards are set. Does any individual firm have an incentive to contact all the other firms in the industry to set common standards? The answer is no, unless the cost of organizing all the firms and negotiating the standards is very small. These conditions are most likely to be satisfied in industries whose products do not change rapidly over time. Unfortunately, such industries, especially if concentrated, may be prone to noncompetitive behavior, ${ }^{11}$ so that one must be careful to insure that the setting of standards does not become a mechanism to exclude competition from new products. In the Radiant Burners case, for example, the Court recognized that standard setting could be an attempt to exclude competition and could support an antitrust cause of action. ${ }^{12}$ In an industry with continual change in product design, by contrast, it would be much more costly to set and maintain standards. Indeed, in an industry where technology is rapidly changing, the costs of setting standards for newly evolving technologies may be so high as to provide no incentive for any independent firm to contribute to the setting of the standards, in which case it is unlikely that standards will be promulgated and followed.

Much standard setting in the United States is done under the auspices of the American National Standards Institute ("ANSI"), an organization of firms, trade associations, technological societies,

- See J. Mooney, R. Schroeder, D. Graybill \& W. Lovejoy, supra note 4, at 234-39.

${ }^{10}$ Uniform operating procedures often include management and accounting systems. Uniform bills of lading, for example, were critical to the development of railroad networks. See infra notes 55-58 and accompanying text.

11 It is easier to agree on a price for a standardized product. R. PoSNER \& F. EAsterbrook, Antitrust: Cases, Economic Notes, and Other Materials 337 (2d ed. 1981).

${ }^{12} 364$ U.S. at 659; see supra notes 3-5 and accompanying text. 
consumer organizations, and government agencies. ${ }^{13}$ ANSI oversees the process of setting voluntary standards covering such matters as sizes, weights, procedures, symbols, abbreviations, and definitions. It ensures that an appropriate degree of consensus is reached with regard to the proposed standard. ${ }^{14}$

131 Encyclopedia of Associations 511 (D. Akey 17th ed. 1982).

14 ANSI recognizes three possible ways to develop consensus for a standard: the canvass method, the accredited organization method, and the standards committee method. Under the canvass method, the sponsoring organization takes a canvass or mail poll of all organizations known to have concern or competence in the subject. The responses to the poll are submitted to ANSI for final approval. The canvass method is used only when an organization already has a set of standards that it wants considered as an American national standard. Some organizations, presumably, do not bother to seek national status for their standards.

When standards do not already exist, ANSI must use either the standards committee method or the accredited organization method. ANSI uses the standards committee method when more than one accredited organization is developing standards for a specific area or when a request for standards is made to ANSI and no accredited organization is working on it. ANSI establishes standards committees, many of which become permanent committees with responsibility for all standards in a certain technical area. An example of this is the X3 standards committee, which has general jurisdiction over standards used for computers and information processing. The standards committee acts both as a referee for various organizations developing standards for a given area and as a developer of standards itself through the use of its technical subcommittees. The committees include representatives from business, consumer, and general interest groups. Membership is not limited in number, although a balance is maintained among the various groups. The secretariat, an organization that acts somewhat like a secretary for the standards committee, reviews membership and submits a membership roll to ANSI for approval.

The accredited-organization method begins by an organization applying to ANSI for accreditation. Approval depends on the organization's having acceptable methods for developing a consensus on a set of standards. The method of developing a consensus is usually similar to that of the standards-committee method.

Standard setting is a complicated procedure. An area is proposed for standardization. The matter is referred to the appropriate standards committee. The standards committee refers the matter to various technical committees, and perhaps to planning committees, for comment. The standards committee then decides whether to authorize the project. If the committee decides to go ahead, the matter is again referred to a technical committee, which begins collecting information from international standards organizations and/or other organizations on proposed standards. Successive drafts are drawn up and circulated to interested groups for comment. Any testing that is done is by private parties at their own expense. Eventually the technical committee submits a draft to the standards committee. Public review is held. Technical committees respond to critical comments and submit a new draft for public review and comments. The review process can be repeated any number of times. The standards committee eventually votes on the proposal. If at least two-thirds of the members vote for it, then it is submitted to ANSI, via the secretariat. If approved by ANSI, the standards are printed in the Federal Register and promulgated by the participating organizations through trade journals, university libraries, or labeling procedures.

The method outlined here for the development and adoption of national standards is largely followed at the international level as well. The principal international standard-setting group, the International Organization for Standardization ("IOS"), helps to coordinate the activities of over 300 international organizations. Members of the IOS include representatives from the national standards group of each participating nation. ANSI represents the 


\section{B. The Need for Coordination in Network Industries}

It may be particularly difficult for a network industry to achieve efficiency without coordination. A network industry, such as the railroad or telephone industry, is composed of many different firms that interact with each other. We will often use the terminology of "nodes" and "links" to describe networks. A node is a point in a network where two or more links intersect. A link is a path between nodes. Any action of a firm that affects one link in the network can affect the costs of all firms using links in the network. One firm's action can create an externality that will not be accurately reflected in a price system. That is, one firm's actions can create costs that it does not bear, but that other firms do. ${ }^{15}$ The simplest way to illustrate this point is by an example concerning the location of firms. Suppose there are three locations (nodes) and three firms. Each firm must locate at one site, as each site can accommodate only one firm. The firms ship products to each other (forming links between the nodes) so that a change of location by any one firm affects the costs of all the others. ${ }^{16}$ The firms produce different products, and the firms differ in their profitability at each site.

It is well known that a decentralized price system ${ }^{17}$ with each firm choosing its most profitable location, may not always achieve the efficient allocation of firms to sites. ${ }^{18}$ The reason is that each firm, in assessing where it should locate, ignores the effect its location has on other firms' transportation costs. The only way to induce each firm, acting in its own interest, to locate optimally would be to have a set of side-payment contracts among the firms that would specify a net payment from each firm to each other firm dependent on the network configuration. ${ }^{19}$ Because total profits are

United States in the IOS.

1s An externality occurs when an agent does not bear the full cost of his actions. For example, pollution represents an externality when polluting firms impose the costs of pollution on society but not on themselves.

${ }_{16}$ The change of one firm's location affects each firm's cost of shipping products between locations.

${ }_{17}$ A decentralized price system consists of prices of goods at each location, prices of each location, and a transport cost borne by the shipper.

18 See Koopmans \& Beckmann, Assignment Problems and the Location of Economic Activities, 25 Econometrica 53 (1957).

10 See Hamilton, Indivisibilities and Interplant Transportation Cost: Do They Cause Market Breakdown, 7 J. URB. Econ. 31 (1980). Hamilton persuasively argues that the configuration of plants around any location is the unpriced resource that causes the inefficient allocation of firms in a decentralized price system, known as the Koopmans-Beckmann result. Id. at 38-40. See generally supra note 18 and accompanying text. 
highest under the optimal allocation of firms to locations, there necessarily exists a set of side payments that will make all firms prefer the optimal spatial configuration. This example with three firms involves six possible network configurations, so that a total of eighteen contingent contracts would have to be specified correctly to induce self-interested firms to locate optimally. ${ }^{20}$ As a network becomes large, the side-payment contract system becomes unwieldy. For twenty locations the number of contingencies would be $4.6 \times 10^{20} .21$

The fact that the decentralized price system alone cannot guarantee an optimal spatial configuration and that an unreasonably large number of contract contingencies is needed to overcome this defect of the price system is not the only problem in an uncoordinated network industry. Even if a network industry could establish an optimal spatial configuration, it would not be able to react properly to change. If a network must expand by one node, ${ }^{22}$ a decentralized price system will fail to provide the correct incentives for the location of the new node. Each firm will want the extra node within its own territory, provided positive revenues result, even if such a decision will lead to greater costs or lower revenues elsewhere in the network. Because independent firms will establish additional locations within their territory without considering the effects such locations impose on the entire system, a network of private firms capable of expansion has a tendency to build excess capacity.

A special problem arises if the construction of a network entails large initial costs, but the use of the network involves constant or continuously declining marginal costs. For example, the added cost of sending one more ton of freight on an existing railroad network, the marginal cost of shipment, may be small compared to the high average fixed cost of the railroad's plant and equipment. In such natural monopolies, prices must exceed marginal costs if firms are to break even, because firms must build and maintain costly networks. ${ }^{23}$ Agreeing on a price for the use of each

20 Three firms, $A, B$, and $C$, could produce six different configurations: $A B C, A C B$, $B A C, B C A, C A B, C B A$. A complete system of side contracts would require a contract between each party. The six configurations would therefore produce 18 possible contracts.

${ }^{21}$ With 20 locations, there are 20 ! configurations, each of which involves $((20 \times 19) \div 2)$ side contracts. $20 ! \times((20 \times 19) \div 2)=4.6 \times 10^{20}$.

22 An additional station in a railroad network or an additional telephone switching facility are examples of an additional node in a network.

${ }^{23}$ In natural monopolies, marginal costs are typically below average costs. A firm selling at marginal cost would never recoup its full average costs. More complicated pricing 
link in the network may be difficult if the network includes independent firms which compete with each other in certain markets. Enforcing any price agreement reached may be even more difficult because each firm has an incentive to cut its price to obtain additional business as long as the price exceeds its marginal cost. ${ }^{24}$

Even if it were possible for firms to reach agreement and adhere to a pricing system with price above marginal cost, improper incentives regarding the use and expansion of the network would arise. Wherever price exceeds the marginal cost of using a link in the network, each firm will have an incentive to try to obtain traffic (e.g., phone calls, people, freight) over its link to gain revenue, regardless of whether the result is inefficient overall routing. In such a situation, firms will become concerned with developing their own feeder traffic, realizing that they cannot rely on other firms to provide them with traffic even if their route is the least costly one to use.

For example, suppose that firm $A$ feeds traffic into node $X$ and also has routes from $X$ to $Y$ and from $Y$ to $Z$. The marginal cost of using link $X Y$ is $\$ 1$ and $Y Z$ is $\$ 2$. Firm $B$ only has a route $X Z$ whose marginal cost of use is $\$ 2.50$. The facts of this example can be represented by the following network configuration:

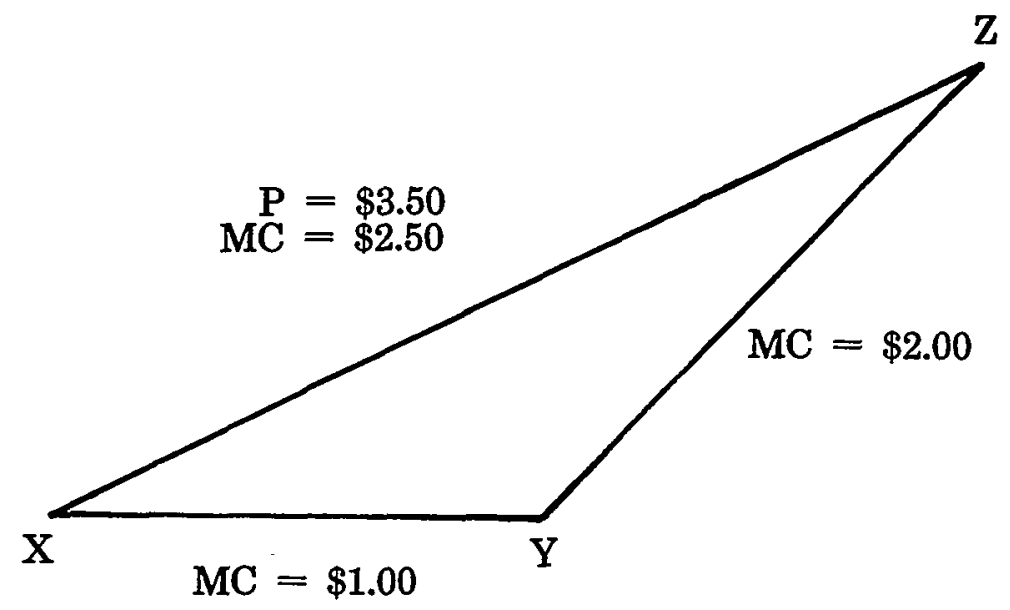

schemes in which the price per unit is not constant could achieve marginal cost pricing. It is often quite difficult to implement such schemes.

24 See R. PosNER \& F. EASTERBROOK, supra note 11, at 97-98. A famous railroad cartel, the Trans-Missouri Freight Association, attempted to solve the price-cutting problem with a complicated scheme of rate setting and review. The entire cartel was declared illegal in United States v. Trans-Missouri Freight Ass'n, 166 U.S. 290 (1897). 
If price is in excess of marginal cost, firm $A$ will have an incentive to route all of its traffic going from $X$ to $Z$ through its own routes $(X Y, Y Z)$ whenever the price of firm $B$ 's direct route exceeds the cost to firm $A$ of using its own routes. In this example, if the price of using the $X Z$ link is $\$ 3.50$, firm $A$ will use its own route, even though fewer resources would be used if firm $B$ 's direct route $(X Z)$ were used. Recognizing this, firm $B$ might expand network capacity and develop its own feeder routes into point $X$. Inefficient routing and inefficient network expansion are thus the result.

Further problems for network industries involve innovation. Without coordinated action, firms in a network industry may be unwilling to introduce new cost-saving innovations. The benefit of a new technology at one location in a network may lower costs at other locations by reducing congestion in the network. Where the network is owned by several different firms, none of them will have the correct incentives to innovate because part of the benefits of the innovation may inure to other firms. Only a complicated set of side payments between firms could correct the situation. Moreover, even if the benefit inures to the innovator initially, the high degree of interaction among firms might make it easy for other firms to learn of and imitate the innovation. Also, since coordination among the inputs used in a network may be critical, ${ }^{25}$ an input innovation may be valuable only if input suppliers to other firms in the network alter their product. But telling other input suppliers how to alter their product may reveal the innovation to these other firms. The fast reaction time of others might deprive the innovator of the ability to recoup his research and development ("R\&D") investment, reducing the incentive to innovate.

Another problem with innovation arises when the innovation is valuable only if all members of the network adopt the innovation. ${ }^{28}$ Any one firm in the network could threaten to render the innovation valueless by refusing to cooperate, and it could use the threat to extract the profits of the innovator. Without an assurance that firms in the network will collectively behave in their own longrun self-interest, an innovator may have little incentive to innovate.

1s A network may require compatible machinery in order to operate correctly, for example.

${ }^{20}$ For example, development of a railroad engine that operates only on a particular rail design would be of little value unless all firms adopted the particular rail design. 


\section{The Market Structure of Network Industries}

If it is very costly to reach consensus among independent firms in a network industry on standards, routing, and expansion, then horizontal integration might arise. The horizontally integrated firm (a single firm in control of an entire network) could internalize the externalities inherent in a network. For example, a horizontally integrated network industry avoids the spatial configuration problems noted above. Because the integrated firm bears all of the costs and receives all of the benefits of a particular location decision, the firm has the incentive to locate its operations correctly.

Standardization of operations and machine compatibility is likely to be very important in network industries. Vertical integration might be a method for a horizontally integrated firm to achieve standardization of its inputs. Vertical integration combined with horizontal integration might also be used to facilitate innovation in networks: since the firm itself would be both the network and its supplier, the firm would not have to worry about exploitation by other firms in the network or about imitation either by other firms in the network or by other suppliers to the network.

\section{Applications}

In this part, we illustrate many of the theoretical points made in part I about the setting of standards and the operation of a network by examining three network industries: the railroad industry, the telephone industry, and the new electronic funds transfer industry.

\section{A. Railroads}

The development of the railroad industry in the period 18501910 illustrates the problems of an industry in which efficient production requires coordination among producing firms. Before 1850, there was little need for coordination among railroads. Most railroads consisted of a single line connecting two points, usually two cities. As these lines expanded, however, efficiency and safety considerations spurred the coordination of geographically separate, but contiguous, sections of track.

The first intersectional railroad, the Western, was also the first to encounter problems with coordination. ${ }^{27}$ Its line connecting Worcester and Albany, completed in 1840, consisted of three sec-

27 A. Chandler, The Visible Hand 96 (1977). 
tions, each of which was originally operated by the section's own staff. ${ }^{28}$ A series of accidents from this decentralized operation culminated in a head-on collision of two passenger cars in 1841, killing two people. ${ }^{29}$ The accident prompted the centralization of Western's operations and the creation of a common precise timetable. ${ }^{30}$ As other lines began to expand regionally, they patterned themselves on Western's organization. ${ }^{31}$

As rail systems grew, cooperation between different regional railroads became necessary to create an efficient national overland transportation network. ${ }^{32}$ The following discusses the railroads' efforts at cooperation, the integration of the rail industry, and the theoretical implications of the railroads' experiences.

1. Early Efforts at Cooperation. The first efforts at coordination among railroads began in the mid-1850's, when railroad executives began to hold meetings regarding freight classification, scheduling, and rates. ${ }^{33}$ They reached agreement on classification and scheduling fairly easily and agreed upon a set of competing freight rates that prevailed from 1857 until the depression of $1873^{34} \mathrm{Al}$ though railroads expanded rapidly during this period, so did demand, particularly as the integration of the rail system made rail transportation increasingly attractive. ${ }^{35}$ But as the depression mounted in 1873 , so did financial pressures and the temptation to cheat on rates.

In 1874, the executives of all major northern rail lines, except one, met to set a formal rate agreement. ${ }^{36}$ The other railroad, the Baltimore and Ohio ("B\&O") declined the invitation, and when it completed its line to Chicago it lowered its Baltimore-Chicago fees

28 Each of the railroad's three operating sections was a separate division, with its own management. The company ran three trains a day in each direction, on a single track, through mountainous terrain, without telegraphic signals. The trains moving in opposite directions met twelve times daily, requiring accurate coordination of schedules. $I d$.

2s Id.

$30 \mathrm{Id}$. at 97.

31 Id. at 98. The coordination of other lines was prompted by the volume of freight traffic rather than the safety concerns that prompted the Western's reforms.

${ }^{32}$ For example, in 1849, a freight shipment from Philadelphia to Chicago took nine weeks and required at least nine transshipments. A transshipment is the transfer of freight from one freight car to another. By 1859 , coordination allowed the freight to pass in three days and required only one transshipment. Id. at 122.

s2 Id. at 125.

si Id. at 126.

ss From 1865 to 1875 freight traffic carried by the nation's 13 major roads more than tripled. The 1880's saw rail freight traffic double again. The Statistical History or THE United States From Colonial Thmes to the Present 727 (1976) (Series Q 280 \& 283).

so A. ChANDLER, supra note 27 , at 137 . 
to below the agreed-upon rate. ${ }^{37}$ During the winter of $1875-76$, the $\mathrm{B} \& \mathrm{O}$ demonstrated the profitability of its independent price cutting, ${ }^{38}$ and other railroads followed the B\&O in lowering prices. ${ }^{30}$ Soon the low rates had everybody-even the B\&O-worried, and the major rail executives met in 1877 to establish a joint executive committee to set rates and, just as important, to apportion traffic. ${ }^{10}$ During 1877 and 1878 there was still comparatively little adherence to agreed-upon rates. ${ }^{41}$ The year 1879 brought a new agreement that produced calm until 1880-81.42 In 1882 a stronger pool was formed, ${ }^{43}$ and this time money was also pooled to compensate those lines that did not get their apportioned share of traffic. This agreement, like its predecessors, succeeded only intermittently. ${ }^{44}$

It took the railroads longer to reach agreement concerning physical integration than it had to reach the initial rate agreements. ${ }^{45}$ In 1861, railroads used different gauges and track designs, ${ }^{46}$ and it was often the case that competing lines entering the same city did not meet." Much of this incompatibility was designed to prevent other railroads from siphoning off feeder traffic. ${ }^{48}$ Railroads eventually began to see the economic advantages of linking their systems and coordinating their operations. Throughout the 1860's and 1870's, numerous conventions of railroad managers were held, and many trade publications were written to foster resolution of these difficulties. ${ }^{49} \mathrm{By}$ the 1880 's the process of

${ }^{37}$ Id. at 138; P. MacAvoy, The Economic Effects of Regulaton 45 (1965).

ss $P$. MacAvoy, supra note 37 , at 49.

${ }^{39}$ A. Chandler, supra note 27 , at 138 . New entrants also cut rates to obtain traffic. The Grand Trunk of Canada line, opened in 1875, entered the market with rates below the agreed-upon rate. $I d$.

${ }^{10}$ Id. The presidents of the major trunk lines asked Albert Fink, who was managing a similar system in the South, to run their new rate setting organization, the Eastern Trunk Line Association. Id.; P. MAcAvoy, supra note 37, at 51-52.

4 P. MacAvoy, supra note 37, at 52-56.

${ }^{12} I d$. at $58,79-91$.

4 Id. at 92 .

14 Id. at $92-95$.

${ }^{45}$ Some physical integration was easy to accomplish. Railroad lines formed joint ventures to build and maintain connecting bridges and intracity belt lines. A. ChandLER, supra note 27 , at 124.

${ }^{16}$ Even by 1881,119 different patterns and 27 different weights of rail were still in use. Fishlow, Productivity and Technological Change in the Railroad Sector, 1840-1910, in OuTput, Employment and Productivity in the United States after 1800, at 583, 633 (NBER Studies in Income and Wealth vol. 30, 1966).

17 A. Chandler, supra note 27 , at 122.

48 Id.

1. Id. at $130-32$. 
coordination that began in the 1850 's was largely complete; ${ }^{50}$ a rail shipment could finally move from one part of the country to another without a single transshipment..1 Switching facilities and belt lines had been built, ${ }^{52}$ a standard gauge was initiated in $1886,{ }^{\mathrm{s3}}$ and a standard rail design was in widespread use by the mid-1890's. ${ }^{54}$

Railroad managers also established uniform operating procedures. For example, on November 18, 1883, all railroads synchronized their clocks. ${ }^{\mathrm{ss}}$ Some of the uniform operating procedures were spurred by outside competition. During the thirty-year period beginning in 1850, independent freight companies, such as Wells Fargo, began to serve as intermediaries between railroads and customers who desired to ship goods. These freight companies handled the complicated transactions with all the different railroads. ${ }^{58}$ This business was extremely lucrative, and the railroads naturally wanted to obtain some of the profits. To do so, however, they needed to establish common operating procedures to reduce the expense of transacting with many railroads when transshipment across different railroads was required. Two innovations were crucial to accomplish this. First, a common bill of lading was introduced to give details of the goods being shipped, the route over which they were to be sent, and the charges levied. ${ }^{57}$ Second, car account offices were established by the major companies to keep track of other firms' cars on their lines and their cars on other firms' lines. ${ }^{58} \mathrm{By}$ the 1880's, the railroads had little need for freight express companies. The railroad industry had been transformed into a small number of multi-unit enterprises, with much coordination of activities.

2. Corporate Integration and Theoretical Implications. By the mid-1880's most railroad executives realized that agreements would not be sufficient to ensure railroad cooperation on expansion, routing, or pricing. For the reasons presented above in the theoretical analysis, the railroads could not rely on other railroads

so Id. at 124.

s1 Id. at 123. See supra note 32.

82 A. Chandler, supra note 27, at 124.

ss Id. at 130.

Fishlow, supra note 46 , at 633 .

s A. Chandler, supra note 27, at 130.

s The freight companies not only expedited freight shipments, but also controlled large fleets of freight cars. Id. at 127-28.

67 Id. at 129 .

s Id. 
to supply them with the feeder traffic so crucial to their solvency. Most turned to integration by building nationwide systems to create their own through traffic. In 1887 the prohibition against railroad pools in the Interstate Commerce Act removed any last hope that interfirm coordination might work. ${ }^{69} \mathrm{By} 1906$, the process of horizontal consolidation had continued to the point where twothirds of the nation's rails were controlled by only seven groups. ${ }^{60}$

Railroad firms increased in size greatly during the last half of the nineteenth century. From 1860 to 1880 , average firm size quintupled; ${ }^{61}$ from 1880 to 1910 , it quadrupled. ${ }^{62}$ As our theory predicts, however, the increase in the network's capacity was not necessarily completed in the most efficient way. As the railroads pursued their empire building, a great deal of overbuilding occurred. In the 1880's more miles of track were built than in any other decade; in the 1890's more mileage was in bankruptcy than in any other decade. ${ }^{63}$

Consistent with our theory, the evolving coordination and integration of the nation's rail system was accompanied by consistent and large increases in productivity. Fishlow estimated that from 1839 to 1910 , annual total factor productivity increases in railroads averaged $3.5 \%$ at a time when the aggregate factor productivity increase in the U.S. averaged less than $1.3 \%{ }^{64}$ Only part of the productivity advance was the result of major technological change. Fishlow found that the gains in productivity due to four important mechanical advances ${ }^{65}$ accounted for only half the increase in productivity from 1870 to $1910 .^{68}$ The other half was apparently due to residual technological advance and economies of scale. ${ }^{67}$ In addition to technology, the blossoming of trade associations, which helped set standards and evaluated new technological proposals, contributed to efficiency. ${ }^{68}$ Much of the period's technological pro-

${ }^{58}$ See Interstate Commerce Act, ch. 104, § 5, 24 Stat. 379, 380 (1887) (codified as amended at 49 U.S.C. § 5(1) (1976)); P. MacAvoy, supra note 37, at 112.

so A. ChandLer, supra note 27, at 174 .

a1 Fishlow, supra note 46 , at 632 .

2 Id.

os A. Chandler, supra note 27, at 147 .

b4 Fishlow, supra note 46 , at 629 .

CS Fishlow examined the productivity effects of four important technological advances: steel rails, increased equipment capacity, air brakes, and automatic couplers. These innovations subsumed a host of lesser innovations. Id. at 634 .

${ }^{\text {Bo }}$ Id. at 644 .

or Fishlow did not estimate the productivity gains resulting solely from the increased operating efficiency of the railroads.

so Fishlow, supra note 46, at 632-33. 
gress was linked to firm size; four of the five most important railroad inventions in the 1800 's ${ }^{69}$ were developed by large railroads, and the origin of the fifth is uncertain. ${ }^{70}$ This confirms our theoretical expectation that vertical integration and innovation, that is, discovering an innovation and capturing the benefits of an innovation for one's own use, are likely to go hand in hand in a network industry.

The history of the American rail network illustrates the theory we presented earlier. It shows that firms gradually increased in size in an attempt to internalize the externalities associated with the operation of a network. The initial setting of standards, though time consuming and difficult, was accomplished without large scale horizontal integration. The eventual horizontal integration of the system was required to address the routing, expansion, and pricing problems of a network. Vertical integration into R\&D proved to be the way to achieve technological advances.

It is important to remember that as long as independent firms in a network interact, our theory predicts that there will exist incentives for inefficient network operation. One excellent illustration is the recent case of Bangor and Aroostook Railroad [the "B\&A"] v. ICC." The B\&A, a feeder railroad, agreed to feed its traffic to the Canadian Pacific Line ("CP"), rather than to others, even in cases where another rail line was the lowest cost shipper. The CP expanded and made payments to the B\&A. ${ }^{72}$ The First Circuit ruled that the B\&A's actions violated the Interstate Commerce Act, which forbids diverting feeder traffic in a way that causes inefficient network utilization. ${ }^{73}$ The $B \& A$ case demon-

- Based on frequency of citation in discussions of technological innovation in railroads, Fishlow claimed that the five most important innovations of the nineteenth century were the use of the telegraph to control train movements (1851), the substitution of steel rails for iron rails (1862), and the development of block signaling (1863), air brakes (1869), and automatic couplers (1873). Id. at 632.

70 Id. The first use of air brakes is uncertain. Some authorities credit the B\&O, but other authorities credit lesser lines. Id. at n.81.

${ }^{71} 574$ F.2d 1096 (1st Cir.), cert. denied, 439 U.S. 837 (1978).

72 Id. at 1102-03.

73 The Act provides that "[a]ll carriers subject to the provisions of this chapter . . . shall not . . . unduly prejudice any connecting line in the distribution of traffic that is not specifically routed by the shipper." 49 U.S.C. $\$ 3(4)$ (1976). The court agreed with a threejudge district court

"that preferential solicitation when done on a 'preconcerted' and 'systematic' discriminatory basis . . . falls within the statutory prohibition of section 3(4) [as preferential routing]. The preferential solicitation dictated by the agreement is without concern for competitive benefits of similar lines and without relationship to the best possible service to the shipper." 
strates that the rail system has not solved all of its externality problems, and that coordinated action is needed to achieve efficiency in a network industry.

\section{B. The Telephone Industry}

The telephone industry is another example of a network. When a long-distance call is made, the call is handled first by the caller's local phone company, then by a hierarchy of switching stations, and finally by the facilities of the receiver's local phone company. Because the phone system is not a single firm but instead consists of AT\&T and several independent phone companies, ${ }^{74}$ it is inevitable that the problems requiring interfirm cooperation will arise in the telephone network. The history and problems associated with operating and planning the long-distance network have been extensively documented elsewhere. ${ }^{75}$ Here we discuss a few problems in the telephone industry to illustrate the difficulties uncovered in the theoretical section.

Revenue from long-distance calls must be allocated between local exchanges and long-distance companies. This sharing involves a complicated procedure based on the amount of capital devoted to long-distance usage. Since the division of long-distance revenue depends on the firm's capital devoted to handling long-distance calls, local phone companies have an incentive to increase the amount of equipment involved in handling long-distance calls. This incentive was at the heart of the dispute in People's Telephone Cooperative $v$. Southwestern Bell Telephone Co ${ }^{76}$ Long-distance calls originating in People's territory were transmitted over General Telephone lines to Bell. People's constructed its own toll lines to connect directly to Bell. Bell refused to interconnect with People's new lines. People's charged that Bell and General Telephone had conspired, in violation of federal antitrust law, to prevent it from increasing its share of capital devoted to long-distance calls and thereby prevent it from increasing its long-distance revenue. ${ }^{77}$ The court stayed the antitrust claim pending exercise by the FCC of its primary jurisdiction over the matter. ${ }^{78}$ Doniphan Telephone Co. $v$.

574 F.2d at 1108-04 (quoting Southern Pac. Ry. v. United States, 277 F. Supp. 671, 685 (D. Neb. 1967), aff'd mem., 390 U.S. 744 (1968)).

"See Lavey, Joint Network Planning in the Telephone Industry, 34 FeD. Coм. L.J. $345,346-48$ (1982).

75 Id.

${ }^{76} 399$ F. Supp. 561 (E.D. Tex. 1975).

I7 Id. at 562 .

78 Id. at 562-63. The FCC ordered that the matter be investigated by an Administrative 
$A T \& T^{79}$ is a similar dispute. Doniphan, an independent telephone company, wanted to construct switching and transmission facilities with connections to Bell at higher levels of the switching hierarchy than was usual. ${ }^{80}$ The new equipment would have quadrupled Doniphan's long-distance revenues. ${ }^{81}$ The FCC denied Doniphan's request, finding it neither desirable nor in the public interest. ${ }^{82}$ These examples demonstrate the incentive for excess capacity in a network that coordination could eliminate.

Perhaps the clearest instance of conflict in network planning and operation comes from the cases involving specialized common carriers who seek to provide their own interexchange service..$^{8 s}$ These companies have claimed that the design and operation of the telephone network has unfairly excluded them from competing. Recent court and regulatory decisions have allowed these independent interexchange companies a much greater role in the market. Moreover, the recent settlement of the government's antitrust suit against AT\&T severs the link between the long-lines network and local operating companies, and it requires local phone companies to charge the same interconnect charge to all providers of interexchange service. ${ }^{84}$ Joint network planning between the long-lines network and local phone companies will presumably continue, subject to antitrust law. How much scope this gives for joint planning remains to be seen, and some inefficiencies in network planning may result.

It may be that technological developments in interexchange service have made inefficiencies in network planning less important relative to the need for providing the opportunity for competition in interexchange service. A serious problem that could arise now, however, concerns the pricing of the local exchanges. Local regulators will be faced with the problem of generating sufficient reve-

Law Judge. People's Tel. Coop., Inc. v. Southwestern Bell Tel. Co., 62 F.C.C.2d 113 (1976).

34 F.C.C. 949 (1963).

so Id. at $962-64$.

s1 Id. at 961 .

s2 Id. at 967-73.

${ }^{33}$ See, e.g., MCI Telecommunications Corp. v. FCC, 580 F.2d 590 (D.C. Cir.) (Execunet II) (AT\&T ordered to provide interconnection), cert. denied, 439 U.S. 980 (1978); MCI Telecommunications Corp. v. FCC, 561 F.2d 365 (D.C. Cir. 1977) (Execunet I) (FCC erred in rejecting MCI tariff), cert. denied, 434 U.S. 1040 (1978).

s4 United States v. Western Elec. Co., 1982-2 Trade Cas. (CCH) I 64,900, at 72,557 (1982) (§ II(B)(3)) (modification of final judgment). For an analysis of the modification of the final judgment, see W. Lavey \& D. Carlton, Economic Goals and Remedies of the AT\&T Modified Final Judgment (unpublished manuscript) (on file with The University of Chicago Law Review) (forthcoming in the Georgetown Law Journal). 
nues to cover the nonusage-sensitive costs of the local phone companies. If local regulators attempt to charge interexchange carriers an access charge per call that is in excess of actual marginal costs, the interexchange carriers will be encouraged to bypass the local exchange. ${ }^{85}$ Although bypass is still relatively rare, the use of existing bypass technology and the development of new bypass technologies would be encouraged by access charges in excess of marginal cost. Moreover, since a large fraction of all interexchange usage is concentrated among relatively few users, bypass could become a real problem within a few years. Of course, this shift away from use of the local exchange would not only be inefficient but would exacerbate the local regulator's problems of raising enough revenue to cover fixed costs. It is too early to tell whether local regulators will have the courage to move to more cost-justified rates, with the financing of fixed costs coming from nonusage-sensitive charges, such as a flat fee for the ability to use the local exchange. ${ }^{88}$ Without such a policy, many of the inefficiencies in network usage we have demonstrated could develop as users adapt their behavior to avoid paying prices in excess of marginal costs.

\section{Electronic Funds Transfer}

The problems involved in the creation of an efficient electronic funds transfer ("EFT") network are analogous to those of the railroad industry of the nineteenth century and illustrate our theory. EFT's problems can be broken down into two general areas: the creation of common standards to facilitate communication between data networks, and the sharing of certain facilities to achieve cost savings. These considerations are not independent of each other.

The EFT industry owes its existence to rapid technological developments. EFT systems have a wide variety of uses. EFT could improve existing banking systems in the use of preauthorization techniques. The payment of a worker (or stockholder or welfare recipient) and his subsequent payment of recurrent obligations (rent, mortgage, utility bills) can involve the time-consuming transfer of pieces of paper between parties. Preauthorization and electronic funds transfer can eliminate the need for transfers between parties. Bill payments can be deposited automatically. Even if receipts are given to acknowledge the transactions, this procedure would save time and paper. ${ }^{87}$

${ }^{\text {Bs }}$ See supra notes $23-24$ and accompanying text.

so Recent FCC rulemaking suggests that federal regulation of communications will move in the direction of cost based rates. See, e.g., Access Charges; MTS and WATS Market Structure, 48 Fed. Reg. 10,319 (1983) (to be codified at 47 C.F.R. $\$ \S 69.1-.610$ ).

87 Arthur D. Littue, Inc., The Consequences of Electronic Funds Transper 4 (1975). 
Another area for the use of EFT is in automated banking services. Many institutions already have automated tellers, which provide around-the-clock service and allow a great expansion of a bank's operating area. ${ }^{88}$ Still another area for EFT utilization involves point-of-sale devices, which could supplement existing cash, check, and credit card methods of financing purchases. There are many ways of implementing EFT in this area, ranging from on-site verification of a customer's check by electronic means to the immediate transfer of funds from the shopper's bank account to the store's account. ${ }^{89}$ This is not an exhaustive survey of possible EFT uses, but it is indicative of the types of possible services. ${ }^{90}$

Cost considerations will spur institutions to contemplate sharing network facilities. A number of banks, for example, could split the cost of a single switching and processing facility for their automatic tellers. Even the teller devices themselves could be shared; the customer would simply identify the bank with which he wanted to communicate. ${ }^{91}$ Point-of-sale devices might need to be shared not only for efficiency, but because of the retailer's reluctance to have the devices of several different firms on his premises. Finally, sharing increases the initial customer base, which might enable certain EFT operations to become profitable more quickly. ${ }^{92}$

Setting common standards is obviously crucial to the successful sharing of network facilities. Various procedures are needed for the different elements of the network to communicate with each other. There would also have to be consensus on measures for fraud protection, error correction, secure-access identification, ${ }^{93}$ and the provision of an audit trail to trace transactions. ${ }^{94}$ This audit trail is similar to the need for a common bill of lading in the

s. Id.

s Id.

* For a description of other uses in banking and payment systems, see id. at 72-74.

1 See id. at 152-53.

92 Id. at 153.

93 Id. at 22, 237.

* For a description of the problems of theft, erroneous transactions, system errors, and the mechanical and procedural means to prevent such problems, see National Commission on Electronic Fund Transegrs, EFT in the United Statzs: Policy Recommendations AND THE Public InTrRest 55-66, 183-94 (Final Report Oct. 1977) [hereinafter cited as NATIONAL COMmISSION]. 
railroad industry. ${ }^{98}$ Coordination problems, if not encountered on a local level, certainly would be experienced as local networks combine to create regional networks and regional networks combine to create a national network.

As our theory would predict, standard setting in the rapidly changing EFT industry was slow in developing. The delay in developing standards is the result of (1) the consensual nature of standard setting and (2) the unwillingness of manufacturer or supplier groups to undertake the expense of determining whether a proposed standard is technically feasible. ${ }^{98}$ The delay can have at least two direct effects: it can slow the development of integrated networks and can freeze the technology at the lowest common denominator.

Based on our theory, we expect that the EFT industry will become dominated by one nationwide or perhaps several large regional firms. The need for horizontal integration to facilitate standard setting is clear. We might also expect that once the network becomes more horizontally integrated, the horizontally integrated firms will vertically integrate into $R \& D .^{97}$

Because of the potential savings from sharing network facilities, other observers have suggested that future EFT systems might best be organized as a national public utility ${ }^{98}$ or at least as interconnected regional utilities. ${ }^{89}$ Concern over the consolidation of EFT networks led Congress in 1974 to establish the National Commission on Electronic Fund Transfers. ${ }^{100}$ The Commission recommended that EFT systems should be licensed, not regulated, with some (unspecified) amount of cooperative arrangements allowed. ${ }^{101}$ It further emphasized that antitrust law should apply in full force to any sharing arrangements. ${ }^{102}$ These conflicting recommendations provide little guidance in determining the allowed amount of interfirm coordination, and this uncertainty has undoubtedly delayed the development of EFT.

ss See supra notes 55-57 and accompanying text.

- See National Commission, supra note 94, at 172.

$\because$ For a detailed analysis of EFT, as well as a slightly different viewpoint, see W. BAXter, P. Cootner \& K. Scott, Retall Banking in the Electronic Age (1977).

9s See ARThur D. LitTle, INC., supra note 87, at 153.

9 See id. at 42 (best technical solution).

100 Act of Oct. 28, 1974, Pub. L. No. 93-495, §§ 201-208, 88 Stat. 1500, 1508-11 (codified at 12 U.S.C $\S \S 2401-2408$ (1976)).

101 See National Commission, supra note 94, at 92-97.

103 See id. at 97-98. See also National Commission on Electronic Fund Transfers, EFT and the Public Interest: A Report of the National Commission on Electronic Fund Transrers 51-52 (Feb. 1977). 


\section{Conclusion}

This paper has presented a simple theory predicting the difficulties that arise when standard setting or networks are involved. We illustrated these difficulties with examples from the railroad and telephone industries and from the relatively new electronic funds transfer industry. We argued that changes in market structure through horizontal and vertical integration are likely to arise in response to these difficulties. The evolution of the railroad industry provides an illustration of these changes in market structure. The theory predicts that the relatively new electronic funds transfer industry will undergo similar horizontal and vertical integration.

It is not easy to balance the efficiency gains of coordinated action against the loss in competition that may result, but the special need for coordinated action in network industries must be recognized. In the early stages of development when an industry is evolving rapidly, coordinated action can have large payoffs. The loss of competition, though always a worry, is less of a worry in a rapidly developing industry with many potential entrants. Yet there is no doubt that industry fear of antitrust liability can retard network industries, especially in their early phases of development. Rules of reason therefore should guide government action regarding network industries to facilitate the gains of coordination. 